\title{
TheFintech Based Entrepreneurs' Intention: A Significant Entrepreneurial Alertness towards Entrepreneurs' Intention in Financial Services Transformation
}

\author{
Masrina Nadia Mohd. Salleh, RahayuTasnim, ShalizaAlwi, MohdShamsul Hassan, \\ NoorFaizahMdZainuddin
}

\begin{abstract}
The technology transformative impact on financial services has been signalled and has been cited as major catalyst in what economist are citing as Fourth Industrial Revolution. The financial services, a vital catalytic role in facilitating the economic transformation and growth of Malaysian economic has been enriched by financial transformation. Fintech is the prominent example of financial transformation and innovative solutions for financial services to stay ahead along with Fourth Industrial Revolution. The generation of the ideas behind this transformation and innovation are an outcome from ideas and intention of individuals. Entrepreneurial Intention (EI) form the attention, experience and action toward an idea to become manifest. The Fintech "ideas" may not become reality without Fintech based entrepreneurs' EI. The intentionality concept has been constantly debated by modern theorist, addressing the important aspects of intention to sustain value or effort despite of interruptions. However, the state of Malaysian Entrepreneurial Intention has devoted to the increasing studies on Entrepreneurial Intention among Malaysian while the Malaysian EI is among the lowest within Asia \& Oceania Efficiency-driven economies. Hence, this study combines retrospection of critical realism with a single case study to provide deep description on question studied
\end{abstract}

Rundown phrases-Alertness, entrepreneurial intention, financial services transformation, Fintech, Fintech based entrepreneurs.

\section{INTRODUCTION}

Fintech, a portmanteau of financial technology is evolving at a rapid speed and driven in part by the favourable regulation, thrust less environment, decentralized process and digital transformation. Fintechdisintermediates the way in which traditional financial service used to operate in offering more stable, diverse and flexible financial services to compel with a shift of customer's behaviour. Financial services served as the highest industry in contributing to Malaysia economy 's GDP and has benefited more than other industries from enhancements in information technologies [1]. Financial services are being supplementary digitized via payment apps, mobile wallets,

Masrina Nadia Mohd. Salleh, AHIBS, UniversitiTeknologi Malaysia, Kuala Lumpur, Malaysia. (Email: nadiasalleh@yahoo.com)

RahayuTasnim, MJIT, UniversitiTeknologi Malaysia, Kuala Lumpur, Malaysia. (Email: rahayu@utm.edu.my)

ShalizaAlwi, School of Accounting and Finance, Taylors University Malaysia, Subang Jaya, Selangor, Malaysia. (Email: Shaliza.Alwi@taylors.edu.my)

MohdShamsul Hassan, AHIBS, UniversitiTeknologi Malaysia, Kuala Lumpur, Malaysia.(Email: diwaniparsi@gmail.com)

NoorfaizahMdZainudin, AHIBS, UniversitiTeknologi Malaysia, Kuala Lumpur, Malaysia. (Email: faizah9.zainuddin@gmail.com)
Revised Manuscript Received on September 14, 2019.

equity crowdfunding platforms and online lending platforms. The role of Fintech in financial services in reshaping financial industry by cutting cost, improving the quality of financial services and creating more diverse financial landscape [2]. In addition to that, the 2008 Global Financial Crises steered to a loss of confidence and gave rise to an emerging new financial services landscape. The occurrence of the Fintechphenomenon has not only attracting new generation that more into tech-savvy and internet things of people but at the same time aid to move financial services into greater productivity which augment the economy activity. This whole Fintechthing is really fascinating and raises a key question on how this Fintechidea is generated at the first place? The Fintech ideas are basically any technological innovations, so how do we look beyond the hype because the reason behind the success for several Fintech is cunning used of technology to solve a customer problem in financial services. These innovative solutions or best portrayed as entrepreneurs' ideas and intention is directed by entrepreneur's states of mind through their alertness towards financial transformation. Without the ideas and intention, the initial strategic template of Fintech based organization in underpinning of new venture development may impossible. Drawing from Entrepreneurial Intentions (EI) concept, the Fintech based entrepreneurs' intention guide their goal setting, communication, commitment, organization, and other kinds of works towards the development of Fintech ideas.

For this paper purposes, at the most general level, the individual entrepreneurs must able to constructs, where possible exploits opportunity in the new market requires resource coordination and allocation. The alertness may differ for different individual. At this point it is pertinent to say that the consistencies of process-based view inherently needed, assume individuals act differently according to how do people work and interact with their experience and surroundings. The study of entrepreneurial intention opens new arenas to theory-based research which directs attention toward complex relationship among entrepreneurial ideas or and consequent outcomes of these ideas.

The topic intention lies at the nexus of cognitive, psychological concerns and behaviours has emerged intensively debated subject moving increasingly from journals focused on psychology [1] to mainstream business and entrepreneurship journals $[3]-[5]$. 


\section{THE FINTECH BASED ENTREPRENEURS' INTENTION: A SIGNIFICANT ENTREPRENEURIAL ALERTNESS TOWARDS ENTREPRENEURS' INTENTION IN FINANCIAL SERVICES TRANSFORMATION}

Yet, due to its emergent character, to date most contributions remained conceptual or have reported results of quantitative study research which merely not discuss on "how" this intention is developed through one's alertness. Discussions of the emergences of new entrepreneurial opportunities often include "eureka" moments, but our understanding of how new opportunities get brought forward is limited. Additionally, alertness is a concept that is starting to gain some traction. Despite its potential, alertness remains understudied due to an ambiguous understanding of the term and particularly because of major measurement issues. Entrepreneurial alertness to opportunity has become an important part of a considerable number of entrepreneurship and displayed the important part of entrepreneurial process of initiation new idea [6] thus deeper understanding of it, is valuable especially for entrepreneurship which highly impact by innovation and technology .

How do Fintech based entrepreneurs developed intention from alertness? In order to answer this question, frame of this paper is follows; (1) This study reviews the Theory of Entrepreneurial Alertness [3]-[5]. This theory stipulates understanding of the phenomenon in the economic development of entrepreneurship. This theory provides imperative clues for exploring dynamic mechanism of alertness in developing intention. (2) Fintech start-up is taken as the object of single case study to explore deep structure, strength and mechanisms [7]-[11] of alertness by means of retrospection. (3) This study proposes some associated propositions through analysis of alertness in entrepreneurial intention. A conceptual model is developed. (4) At the final stage, a conclusion and contribution of the study are summarized, and limitations and future directions are provided.

\section{LITERATURE REVIEW}

\section{A. Intention}

The field of entrepreneurship have long tried to explain who entrepreneur is and one is created [7], [10]-[12]. The interest to describe entrepreneurship as the process that entrepreneur goes through, often mentioned as entrepreneurial process. Entrepreneurial process is often centered from idea recognition and realization but missing the fundamental core that these ideas derived by intention [13]. From psychological standpoints, intention is closely linked with courage, persistent and perseverance and described as a direction toward new venture creation. The first phase before one decided to exploit opportunity is to develop psychological intention to determine whether or not the exploitation is favorable or desirable option. Entrepreneurial intentions likely regarded as a vital influencing factor in process of being entrepreneur and during entrepreneurial process. Intentions occupy a central position in the exploration of behaviors and relevant in the managerial literature

\section{B. Alertness}

The capabilities of entrepreneurs to discover opportunity, assemble resource, organize and adopt it into realization are essential during entrepreneurial process to exploit the opportunity. However, this existing developmental research mostly focuses on entrepreneurial competencies and the interplay between biologically or demographically based factors and developmental context, is rather silent with regard to entrepreneurial influencing factors, such entrepreneurial alertness. The concept of Entrepreneurial Alertness arrived from the Theory of Entrepreneurial Alertness by Israel M. Kirzner's Theory of Entrepreneurial Alertness (EAS) is one of the most significant contributors to the theory of entrepreneurship in economics. This theory stipulates understanding of the phenomenon in the economic development of entrepreneurship. In [12] work is a distinction between Robbinsian maximizing and entrepreneurial alertness, delineated Entrepreneurial Alertness as the ability of individual not to overlook some possible opportunities without having to search. Adding to that, in [12] later study, EAS has been illustrated as an inspired tendency of an individual to formulate an outcome of the future. While, latest in 2000, in [12] defined as the ability to perceiving potential opportunities that might not be seen by others. Entrepreneur that is more alert tend to see opportunities and utilized information differently. Commenting on Kirzner's theory of entrepreneurship, EAS potentially stipulated insight on an entrepreneurial element in economic behavior [14]. Entrepreneurial alertness allow entrepreneur to search and discover changes in environmental and adjustment easily made on the existing mental framework which not match with existing information.

The nature of entrepreneurial alertness is an opportunity only exists when it is being recognized by entrepreneurs. Some may motivate to see the opportunity, and some may not have motivated and ignored the opportunity. In other words, this may happen when individual switch off or on their alertness system, interest to notice is found to be one of the human agents to alert or not to alert on the potential opportunity.

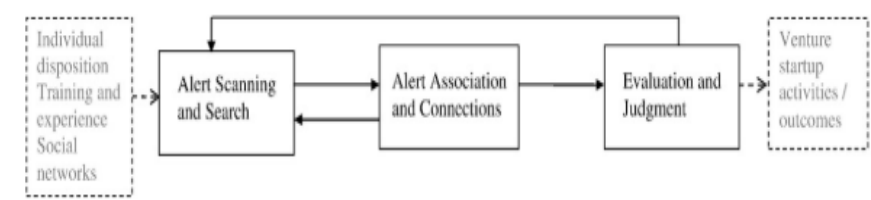

Fig. 1. Model of entrepreneurial alertness [15]

Consistent with [12] early work and the role of awareness of gaps when new opportunities present themselves, alert searching, and scanning refer to constantly scanning the market or environment and searching for new information, changes, and shifts overlooked by others. This reflects the importance of alertness during the early phase of opportunity discovery as contended by [16] Adding to that, in [16] have confirmed a significant relationship between

EAS as a cognitive factor of EI. Adding to that empirical study by [16] has confirmed that individual with strong entrepreneurial alertness

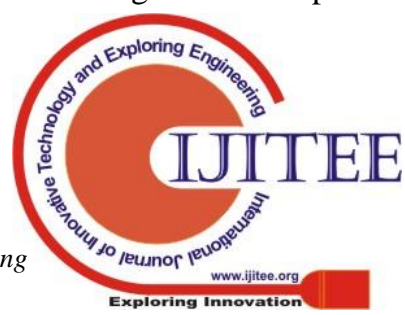


tended to have strong entrepreneurial intentions. EAS found to be important since it has strong correlation to entrepreneurial intention or behavior [17]. Extending alertness as a part of the entrepreneurial cognition process, this dimension involves pre-existing knowledge, preparedness, and sensitivity to new opportunities. The second dimension, alert association and connection, involves pulling together disparate pieces of information and building them into coherent alternatives. In their study discovered an individual alertness entangled with a sequential process of cognitive development in recognizing possible opportunities. This sequential process of cognitive development comprises scanning, searching, association, connection, evaluation, and judgment, which the process of information scan recognition, irrelevant information association and later business ideas evaluation as the sequential processes of cognitive development. When individual is alert with information in an environment, they tend to continually and unconventionally explore new ideas lead to a continuous information perceived and constitutes an individual perceptual information base.

This notion on the cognitive ability can be responding to the ability of entrepreneurs to discover new opportunity best refers to "innovativeness". The individual innovativeness has been addressed by as the awareness towards opportunity as one of significant ability for entrepreneurs. EAS has mostly been explored within entrepreneurial studies that highly impact by innovation. This portrayed the importance of EAS disposition in predicting EI within Fintech start-ups since Fintech behavior is highly impact by innovation. Most recent researchers have continued to advance debates that alertness implicates a proactive stance in regard to a number of cognitive capacities and processes such as prior to knowledge and experience, recognition of pattern, skills in processing information from market and environment and social interactions. Proactive is, by all means, refer as the ability of an individual to identify opportunities without been affected by any obstacles or constraints. Equally important, it leads individuals to take initiative and act upon to influence environments and persevere until meaningful change happens.

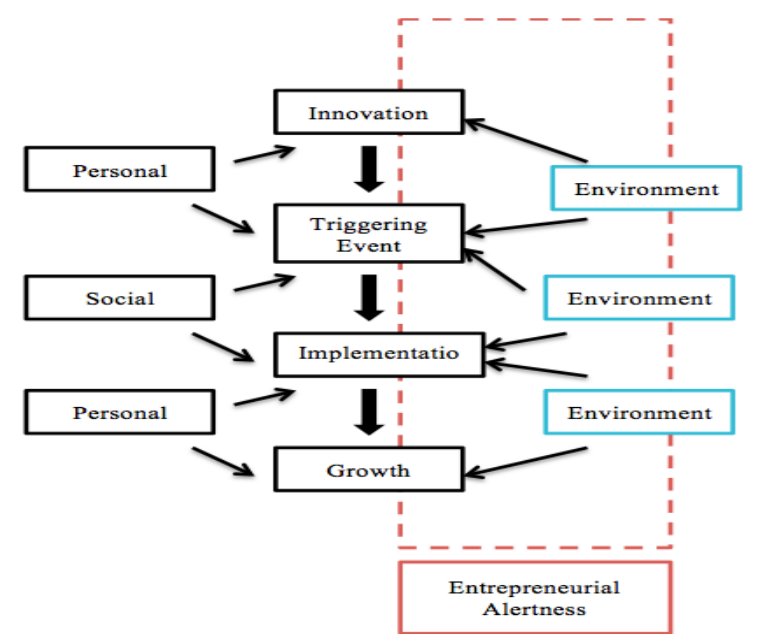

Fig. 2. Entrepreneurial alertness in entrepreneurial process [26], [28]

The differences in entrepreneurial alertness can be attributed to differences in the schemata used for sense- making in response to stimuli (whether external or internal). Alertness comprised of three dimensions; 1) Systematically or non-systematically scan the environment and search information. EAS closely associated with scanning and search, association and connection and evaluation and judgement[18].

\section{RESEARCH DESIGN}

\section{A. Research Methodology}

Case study as one of the research method commonly used in many situations to contribute depth knowledge of individual, group, organizational, social, political and related phenomenon. For the purpose of dynamic and repeated follow-up evaluation of events, this methodology is fit to the questions of "why" and "how". Case study, by all mean is one of several forms of social science research to investigate a contemporary phenomenon in its real-situation context specifically when boundaries and between phenomenon and context may not be clearly evident.

Case study provides in depth description and details for the question studied, which can be used to perform vertical analysis and study of the same case at different point. Thus, this study aims to discuss how Fintech based entrepreneur is developing intention through alertness in certain phenomenon featured by significant and criticality. Hence, single case study is chosen.

\section{B. Case Selection}

Case is selected after question is been defined and research method is selected. Hence, case selection is based on the question and the theories to be developed. In this study, an entrepreneur, the founder of Fintech based start-up referred as FinTech Co is selected. This case is based on real Fintech based entrepreneur and company, but the entrepreneur and company are being renamed to preserve the anonymity requested. All detail is otherwise accurate except where confidentiality or competitiveness issues arise; in which case the data have been suppressed or generalized entrepreneur (the one that developed this Fintech's idea) is selected as research object. The main reasons are; (1) The Fintech Co is developed through the intention of the founder and such intention are directed by entrepreneur's states of mind through their alertness towards financial transformation. Thus, the alertness of the founder, through his/her experiences can provide rich materials for the study of "how" this intention is developed through one's alertness. (2) The Fintech Co. is one of pioneers of Fintech based start-up in Malaysian market. Initially, the founder has to confront with "denial" stage of transformation where people don't really believe in Fintech's idea and the acceptance is really unfavorable in the early period of the idea's establishment. Essentially, as a pioneer of such "disruptive" and "innovative" idea, the founder may see and utilized information, and such sequential process of cognitive

development comprises of
scanning,
searching,
$\begin{aligned} & \text { Published By: } \\ & \text { Blue Eyes Intelligence Engineering } \\ & \text { \& Sciences Publication }\end{aligned}$


THE FINTECH BASED ENTREPRENEURS' INTENTION: A SIGNIFICANT ENTREPRENEURIAL ALERTNESS TOWARDS ENTREPRENEURS' INTENTION IN FINANCIAL SERVICES TRANSFORMATION

association, connection, evaluation, and judgment represent "how" the founder alert with the financial transformation.

\section{Reliability and Validity}

This case study is conducted based on relevant judgement criteria on reliability and validity. The reliability and validity include construction, internal and external validity, and reliability criteria. Reliability concerns with the capability of different researcher to make same observations of a given phenomenon if and when the research is conducted using similar method (s) and procedure (s). Validity is to assess the accuracy of findings as best described by the researcher and informants [19]. In general, validity concerns with degree to which an account is truthful. The method employed to meet the required standards are presented in Table I.

Table- I: Reliability and validity assurance strategies [18], [20]-[24]

\begin{tabular}{|c|c|c|c|}
\hline $\begin{array}{c}\text { Judgement } \\
\text { Indicative }\end{array}$ & $\begin{array}{c}\text { Case Study } \\
\text { Strategy }\end{array}$ & $\begin{array}{c}\text { Phase of } \\
\text { Use }\end{array}$ & $\begin{array}{c}\text { Detailed } \\
\text { Implementation }\end{array}$ \\
\hline $\begin{array}{l}\text { Construction } \\
\text { Validity }\end{array}$ & $\begin{array}{c}\text { Multiple data } \\
\text { sources } \\
\text { Personnel } \\
\text { verification } \\
\text { Evidence claim }\end{array}$ & $\begin{array}{c}\text { Data } \\
\text { collection }\end{array}$ & $\begin{array}{l}\text { In-depth interview, } \\
\text { observation, informal } \\
\text { channels and second- } \\
\text { hand information } \\
\text { (Table II) } \\
\text { Verification of the } \\
\text { detailed description } \\
\text { or theme by the } \\
\text { investigation object, } \\
\text { and feedback from } \\
\text { such object } \\
\text { Theoretical } \\
\text { foundation (raw } \\
\text { data), proposition } \\
\text { formation }\end{array}$ \\
\hline $\begin{array}{l}\text { Internal } \\
\text { validity }\end{array}$ & $\begin{array}{c}\text { Self-check of } \\
\text { member } \\
\text { Requested } \\
\text { observation and } \\
\text { intensive } \\
\text { description }\end{array}$ & $\begin{array}{c}\text { Data } \\
\text { analysis }\end{array}$ & $\begin{array}{l}\text { Investigation object } \\
\text { was questioned by } \\
\text { other members of } \\
\text { research to check the } \\
\text { interpretation and } \\
\text { conclusion made by } \\
\text { researcher } \\
\text { Detailed description } \\
\text { of the phenomena }\end{array}$ \\
\hline $\begin{array}{l}\text { External } \\
\text { validity }\end{array}$ & $\begin{array}{l}\text { Theoretical } \\
\text { guidance } \\
\text { Propositions }\end{array}$ & $\begin{array}{l}\text { Research } \\
\text { design } \\
\text { Data } \\
\text { analysis }\end{array}$ & $\begin{array}{l}\text { Review of related } \\
\text { theoretical } \\
\text { foundations within } \\
\text { the case studied }\end{array}$ \\
\hline Reliability & $\begin{array}{l}\text { Case study } \\
\text { scheme } \\
\text { Case study } \\
\text { database }\end{array}$ & $\begin{array}{l}\text { Research } \\
\text { design } \\
\text { Data } \\
\text { collection }\end{array}$ & $\begin{array}{c}\text { Research discussion } \\
\text { and consent } \\
\text { Files and database } \\
\text { are sorted and well } \\
\text { managed }\end{array}$ \\
\hline $\begin{array}{l}\text { External } \\
\text { validity }\end{array}$ & $\begin{array}{l}\text { Theoretical } \\
\text { guidance } \\
\text { Propositions }\end{array}$ & $\begin{array}{l}\text { Research } \\
\text { design } \\
\text { Data } \\
\text { analysis }\end{array}$ & $\begin{array}{l}\text { Review of related } \\
\text { theoretical } \\
\text { foundations within } \\
\text { the case studied }\end{array}$ \\
\hline
\end{tabular}

\section{Data Collection and Sources of Data}

The collection of data is performed based on the principle of multiple data sources. The purpose is to achieve data triangulation; which data sources include nature of data sources. Sources of data are presented in Table II.

Table- II: Reliability and validity assurance strategies

\begin{tabular}{|c|c|c|}
\hline Process of Analysis & Level of Analysis & $\begin{array}{c}\text { Description of } \\
\text { Analysis }\end{array}$ \\
\hline Engagement / sense- & Reading the case & Interview transcript \\
\hline
\end{tabular}

\begin{tabular}{|c|c|l|}
\hline making & materials & $\begin{array}{l}\text { is repeatedly read } \\
\text { and interview } \\
\text { process review to } \\
\text { get depth } \\
\text { information and } \\
\text { emotion cognition }\end{array}$ \\
\hline Categorisation & $\begin{array}{c}\text { Case is thoroughly } \\
\text { diagnosed }\end{array}$ & $\begin{array}{l}\text { Core themes are } \\
\text { highlighted }\end{array}$ \\
\hline $\begin{array}{c}\text { Association/pattern } \\
\text { recognition }\end{array}$ & $\begin{array}{l}\text { Developing intra } \\
\text { case theme }\end{array}$ & $\begin{array}{l}\text { Themes of different } \\
\text { analysis unit are } \\
\text { compares }\end{array}$ \\
\hline Interpretation & Write up & $\begin{array}{l}\text { Explanatory text } \\
\text { based is written } \\
\text { according to the } \\
\text { raw material }\end{array}$ \\
\hline Explanation & $\begin{array}{l}\text { Interpretative } \\
\text { theoretical } \\
\text { framework is } \\
\text { formed through } \\
\text { synthesis } \\
\text { identify and reveal } \\
\text { the uniqueness of } \\
\text { the original data }\end{array}$ \\
\hline
\end{tabular}

\section{E. Data Analysis}

The purpose of this study is to discuss in depth "how" intention of Fintech's founder is developed through the founder's alertness. Thus, researcher needs to explore the experience of the founder (events) that occurred during the establishment of the intention. According to [12] early work and the role of awareness of gaps when new opportunities present themselves, alert searching, and scanning refer to constantly scanning the market or environment and searching for new information, changes, and shifts overlooked by others. This reflects the importance of alertness during the early phase of opportunity discovery. Thus, researcher need to carefully identify and explore how this founder is scanning, searching, through one's experience, events (environment), association, connection, evaluation, and judgment. Therefore, after interview data was transcribed, the repetition of transcription reading, and interview process reviewing were performed. Significant semantic fragments using text analysis, which aided by nvivo was executed. During the process of data analysis, guidelines and principles were adopted and presented in Table III. Research propositions are exhibited in Table IV.

Table- III: Reliability and validity assurance strategies

\begin{tabular}{|c|c|l|}
\hline $\begin{array}{c}\text { Process of Analysis } \\
\begin{array}{c}\text { Engagement / sense- } \\
\text { making }\end{array}\end{array}$ & $\begin{array}{c}\text { Level of Analysis } \\
\text { materials }\end{array}$ & $\begin{array}{c}\text { Description of } \\
\text { Analysis }\end{array}$ \\
\hline $\begin{array}{c}\text { Categorisation } \\
\text { is repeatedly read } \\
\text { and interview } \\
\text { process is review to } \\
\text { get depth } \\
\text { information and } \\
\text { emotion cognition }\end{array}$ \\
\hline $\begin{array}{c}\text { Association/pattern } \\
\text { recognition }\end{array}$ & $\begin{array}{l}\text { Case is thoroughly } \\
\text { diagnosed }\end{array}$ & $\begin{array}{l}\text { Core themes are } \\
\text { highlighted } \\
\text { case theme }\end{array}$ \\
\hline
\end{tabular}




\begin{tabular}{|l|l|l|}
\hline Interpretation & Write up & $\begin{array}{l}\text { Explanatory text } \\
\text { based is written } \\
\text { according to the } \\
\text { raw material }\end{array}$ \\
\hline Explanation & $\begin{array}{l}\text { Enfolding } \\
\text { literatures }\end{array}$ & $\begin{array}{l}\text { Interpretative } \\
\text { theoretical } \\
\text { framework is } \\
\text { formed through } \\
\text { synthesis to } \\
\text { identify and reveal } \\
\text { the uniqueness of } \\
\text { the original data }\end{array}$ \\
\hline
\end{tabular}

\section{RESULTS AND DISCUSSION}

Table- IV: Evidence of the case study

\begin{tabular}{|c|c|}
\hline Dimension & Evidence \\
\hline $\begin{array}{c}\text { Entrepreneurial } \\
\text { Alertness }\end{array}$ & \\
\hline $\begin{array}{l}\text { Scanning and } \\
\text { search }\end{array}$ & $\begin{array}{l}\text { "..I'm still the greatest fans is still the story } \\
\text { telling, you know , marketing if you like , } \\
\text { branding and all that but at the same time I still } \\
\text { need to understand the diff context. How the } \\
\text { other things like finance, technology interplay } \\
\text { with what the brand all about, this is important } \\
\text { pillars to build the brand..." (EAS1-1) } \\
\text { "..I think if you have ermm I like to retained ... } \\
\text { sense of curiosity, you know you will never } \\
\text { stop. Imagine, I don't get full education, don't } \\
\text { have my o level in my education, fail to get } \\
\text { degree. for me education continue not only on a } \\
\text { piece of paper. You should continuously } \\
\text { educating yourself.so, I do read a lot.." (EAS1- } \\
\text { 2) } \\
\text { "..trying to get myself embrace with } \\
\text { development. And try to learn areas around my } \\
\text {..if you like.. because there are many areas } \\
\text { around, there are so many aspects in } \\
\text { crowdfunding. So many aspects to it. There is } \\
\text { technology aspect on it, there is financial aspect } \\
\text { on it and there is social dimension aspect on } \\
\text { it.." (EAS1-3) }\end{array}$ \\
\hline $\begin{array}{l}\text { Second-hand } \\
\text { information }\end{array}$ & $\begin{array}{l}\text { Time range: January- September } 2019 \\
\text { The contents involve information on how } \\
\text { founder scan and search information that is } \\
\text { general lack awareness of ECF, with less than } \\
10 \% \text { knowing what it is as opposed to overseas } \\
\text { market. }\end{array}$ \\
\hline $\begin{array}{l}\text { Association and } \\
\text { connection }\end{array}$ & $\begin{array}{l}\text { "..As entrepreneurs before, I had difficulties. } \\
\text { Difficulties in having single investor that } \\
\text { can..ermm where things can go rapidly wrong. } \\
\text { They are injecting money and you are injecting } \\
\text { your labour and ideas and its not an equal } \\
\text { partnership, money seems to be predominant if } \\
\text { you like it can dictate the partnership and can } \\
\text { very vulnerable, the agreement, the contract is } \\
\text { not fully synchronize , it can vulnerable to } \\
\text { investors and can be predatory.." (EAS2-1) } \\
\text { "..Elain and I, also been entrepreneurs before } \\
\text { and we know the difficulties of raising funds , } \\
\text { more so when you are small companies without } \\
\text { track records. We discussed the ideas of } \\
\text { crowdfunding, I think } 7 \text { and } 8 \text { years ago..." } \\
\text { (EAS2-2) } \\
\text { “..Fintech can last or do is really address some } \\
\text { of the biggest social issues that confront us. } \\
\text { Issues like inequality, opportunity as well. I } \\
\text { think inequality of opportunity. Its } \\
\text { democratisation of wealth, all of this things I } \\
\text { mentioned before.." (EAS2-3) } \\
\text { “..With equity crowdfunding , it actually give } \\
\text { them great opportunity and allow them to pitch } \\
\text { to a wider audience. The audience that might }\end{array}$ \\
\hline
\end{tabular}

not look purely on the basis financial return, but, hey, I like your social agenda..” (EAS2-4)

"..Imagine where in Finance Fintecharea, you got intelligence into where $\mathrm{u}$ had to use your money effectively, $\mathrm{u}$ know, $\mathrm{u}$ can maximize the yours, $\mathrm{u}$ know, the worth that $\mathrm{u}$ have at any given time. Now it's we do not, we have money here in there. Its either not been used effectively, of course there is factoring risk and anything else to evaluate your risk tolerance and all that but genuinely with all smart algorithm and everything else, you not going to lose your money, you can effectively manage your wealth much better than what you're doing right now. You can create more wealth and value for yourself, much more certain.." (EAS2-5)

"..The centimediation of P2P, finance without going to bank, and look the role of central banks.. I am not saying that they have no value, but again ..u know. If you look at role of banks for example, and the whole financial system during financial crisis 2008...even now.."deucth bank" ..money laundering.." (EAS2-6)

"..also been entrepreneurs before and we know the difficulties of raising funds, more so when you are small companies without track records.." (EAS2-7)

\begin{tabular}{l|l} 
Second-hand & Time range: April - September 2019
\end{tabular}

information

The contents involve information on the business ideas are basically a blockchain enhanced Equity Crowdfunding online platform, matching businesses who are seeking growth and funding with investors to partner in building sustainable world companies (EAS2-8)

This business idea basically seeks to leverage technology as a tools to facilitate and promote transparency and good governance in investing (EAS2-9) 
THE FINTECH BASED ENTREPRENEURS' INTENTION: A SIGNIFICANT ENTREPRENEURIAL ALERTNESS TOWARDS ENTREPRENEURS' INTENTION IN FINANCIAL SERVICES TRANSFORMATION

\begin{tabular}{|c|c|}
\hline $\begin{array}{c}\text { Evaluation and } \\
\text { judgement }\end{array}$ & $\begin{array}{l}\text { "..We believe there are great talent out there, } \\
\text { and we would do our best to help them get } \\
\text { funded. So there is how essentially, I wouldn't } \\
\text { say we stumbled into it, I mean we have been } \\
\text { working with whole concept of crowdfunding } \\
\text { concept since } 7 \text { - } 8 \text { years ago.." (EAS3-1) } \\
\text { "..We still believe on the power of } \\
\text { crowdfunding. The trends support us, and I } \\
\text { think it is a high level of human consciousness. } \\
\text { We have tools to collaborate much more } \\
\text { effectively.." (EAS3-2) } \\
\text { "..we developed Syariah } \\
\text { crowdfunding model which is different from } \\
\text { the Grammy bank model which from micro } \\
\text { investment because its p2p and crowdfunded } \\
\text { and Syariah compliance.." (EAS3-3) } \\
\text { "..Because there is many areas around, there are } \\
\text { so many aspects in crowdfunding. So many } \\
\text { aspects to it. There is technology aspect on it, } \\
\text { there is financial aspect on it and there is social } \\
\text { dimension aspect on it. hmmm..psychology } \\
\text { hmm if you like. The story talent. The ...social } \\
\text { media.. hmm. You know, marketing...its sort of } \\
\text { this thing. probably things that I used to do but } \\
\text { still there is financial you know..very2 far.." } \\
\text { (EAS3-4) } \\
\text { "..Initially Somehow, Bank Negara really likes } \\
\text { it and it's like a smart cookies in there and } \\
\text { considered to give banking license but then the } \\
\text { legal sides concerning about money laundering } \\
\text { KYC, which is ridiculous, so they were very } \\
\text { hesitant to push this without working full } \\
\text { existence in the system they try to push us to } \\
\text { work with bank which is not very keen to do its } \\
\text { like you asking a new renewable company to } \\
\text { work with old major.." (EAS3-5) }\end{array}$ \\
\hline $\begin{array}{l}\text { Second-hand } \\
\text { information }\end{array}$ & $\begin{array}{l}\text { Time range: April - September } 2019 \\
\text { The contents involve information on grant of } \\
\text { RM150K from Cradle awarded to the founder's } \\
\text { company to develop on Online Islamic } \\
\text { Microfinance Portal-it's a crowdfunding portal } \\
\text { on Syariah principles to assist underserved } \\
\text { global micropreneurs (EAS3-6) } \\
\text { The second content involve information on how } \\
\text { the founder contrast his "regular individuals" } \\
\text { with professional investors and lenders like } \\
\text { banks, venture capitalist and angel investors } \\
\text { (EAS3-7) }\end{array}$ \\
\hline Intuition & $\begin{array}{l}\text { "..I left my comfortable job in advertising. I } \\
\text { was a very senior advertiser. I had many career } \\
\text { opportunities, job offers, in overseas as well.." } \\
\text { (EAS4-1) } \\
\text { "..also been entrepreneurs before and we know } \\
\text { the difficulties of raising funds, more so when } \\
\text { you are small companies without track } \\
\text { records.." (EAS4-2) }\end{array}$ \\
\hline $\begin{array}{c}\text { Entrepreneurial } \\
\text { Intention }\end{array}$ & $\begin{array}{l}\text { “..I always felt like a home being an } \\
\text { entrepreneur rather than working with large } \\
\text { corporation. It wasn't easy working for large } \\
\text { companies. I find them stively } \\
\text { (suffocated).."(EI1-1) } \\
\text { “..You know as entrepreneurs, legal agreement } \\
\text { is very expensive, we lied on the lawyer drafts } \\
\text { agreement and we could done better. On this } \\
\text { part I take the responsibility. We should have } \\
\text { title agreement with him. But you know it can } \\
\text { be resolved favorly. In term of delivery, It was } \\
\text { very clear who was negligent. I meant if you } \\
\text { are not satisfied, there are so many ways to } \\
\text { resolve. We should not resolve it being } \\
\text { aggressive..anyway..so that is kind of } \\
\text { experience.." (EI1-2) }\end{array}$ \\
\hline
\end{tabular}

\begin{tabular}{|c|c|}
\hline & $\begin{array}{l}\text { "..I left my comfortable job in advertising. I } \\
\text { was a very senior advertiser. I had many career } \\
\text { opportunities, job offers, in overseas as well.." } \\
\text { (EI2-1) } \\
\text { "..also been entrepreneurs before and we know } \\
\text { the difficulties of raising funds, more so when } \\
\text { you are small companies without track } \\
\text { records.." (EI2-2) }\end{array}$ \\
\hline \multicolumn{2}{|l|}{$\begin{array}{l}\text { Cognitive ability } \\
\text { (personality) }\end{array}$} \\
\hline Innovativeness & $\begin{array}{l}\text { "..to explore more effective ways where we } \\
\text { leverage on technology. Where we are not like } \\
\text { the mercy on one single investors where we can } \\
\text { get small investment from large crowd rather } \\
\text { than rely on one single person.." (CO1-1) } \\
\text { "..of course this is a huge disruptor. People now } \\
\text { talking about, you become your own personal, } \\
\text { can become your bank yourself. All the services } \\
\text { provided you can just ..you can choose } \\
\text { whatever services you want. hmmhmm. its...we } \\
\text { are really into the phase where everything } \\
\text { become digitalized.." (CO1-2) }\end{array}$ \\
\hline $\begin{array}{l}\text { Second-hand } \\
\text { information }\end{array}$ & $\begin{array}{l}\text { Time range: April - September } 2019 \\
\text { The contents involve information on founders' } \\
\text { innovativeness in leveraging Blockchain } \\
\text { enhanced Equity Crowdfunding online platform } \\
\text { to deliver extensive services supporting } \\
\text { companies to stimulate positive social benefits } \\
\text { through entrepreneurship. (CO1-3) } \\
\text { The contents involve information on founders' } \\
\text { eagerness in stimulating new planes of thought } \\
\text { and often challenges the convention with cool } \\
\text { and innovative ideas. (CO1-4) }\end{array}$ \\
\hline Creativity & $\begin{array}{l}\text { "..imagine where in Finance Fintech area, you } \\
\text { got intelligence into where u had to use your } \\
\text { money effectively, u know, u can maximize the } \\
\text { your, u know, the worth that u have at any } \\
\text { given time. Now its we do not, we have money } \\
\text { here in there. Its either not been used } \\
\text { effectively, of course there is factoring risk and } \\
\text { anything else to evaluate your risk tolerance } \\
\text { and all that but genuinely with all smart } \\
\text { algorithm and everything else, you not going to } \\
\text { lose your money, you can effectively manage } \\
\text { your wealth much better than what you're doing } \\
\text { right now.." (CO2-1) }\end{array}$ \\
\hline $\begin{array}{l}\text { Second-hand } \\
\text { information }\end{array}$ & $\begin{array}{l}\text { Time range: April - September } 2019 \\
\text { The contents involve information on how the } \\
\text { founder address "now everyone can be an } \\
\text { angel", a nod to the democratisation effect the } \\
\text { business has given to individual to invest in } \\
\text { early stage companies that have potential to } \\
\text { grow. (CO2-2) }\end{array}$ \\
\hline Self-esteem(belief) & $\begin{array}{l}\text { "..I see..uknow..there are some demographic } \\
\text { factors, there are lots of factors make me } \\
\text { believe that crowdfunding can become a much } \\
\text { more powerful force, and especially when, now } \\
\text { we line together with Blockchain technology, } \\
\text { and there will a lots of exciting things are going } \\
\text { to happen.." (CO3-1) } \\
\text { "..I like the fact I am doing sunny for the sake } \\
\text { of mankind or particular group, your helping } \\
\text { disadvantage and whatever.." (CO3-2) }\end{array}$ \\
\hline
\end{tabular}




\begin{tabular}{|c|c|}
\hline Openness & $\begin{array}{l}\text { "..I believe that you have to create changes in } \\
\text { your life..you know, take on your chances. } 34 \\
\text { years career in advertising, I don't think I would } \\
\text { be proud now if I stayed. You know..so.. you } \\
\text { got nothing to fear but fear to yourself and why } \\
\text { not give a shot.." (CO4-1) }\end{array}$ \\
\hline Proactiveness & $\begin{array}{l}\text { "..It was early days in US as well, so when we } \\
\text { started. Then we decided that we would create } \\
\text { rather than take entrepreneurs whatever there is } \\
\text { social agenda, where there is very small } \\
\text { entrepreneurs, start with that basis first.." (CO5- } \\
\text { 1) }\end{array}$ \\
\hline $\begin{array}{l}\text { Second-hand } \\
\text { information }\end{array}$ & $\begin{array}{l}\text { Time range: April - September } 2019 \\
\text { The contents involve information on the } \\
\text { possible reason why this business idea is } \\
\text { unattractive may due to the fact that the period } \\
\text { by which the investors are required to hold their } \\
\text { shares in the ECF issuer until it goes for IPO or } \\
\text { it acquired (CO5-2) } \\
\text { The content involve the informant claim that his } \\
\text { strategy had } 80 \% \text { success rate and he much } \\
\text { believes that synergies created within the } \\
\text { portfolio reduced the risk of investment (CO\%- } \\
\text { 3) }\end{array}$ \\
\hline $\begin{array}{c}\text { Prior knowledge and } \\
\text { experience }\end{array}$ & \\
\hline Failure experience & $\begin{array}{l}\text { ".I jumped into it and I got some equity with } \\
\text { them as well. One part with negotiation. } \\
\text { Unfortunately, we closed to secured with major } \\
\text { bank in US. We were actually working trade } \\
\text { finance, automating trade finance, and then } \\
9 / 11 \text { happened, and the impact it had... } \\
\text { everything was very cautious, and that event } \\
\text { gave major impact. The major shareholders } \\
\text { decided to shut down the company.." (BE1-1) } \\
\text { "..You know as entrepreneurs, legal agreement } \\
\text { is very expensive, we lied on the lawyer drafts } \\
\text { agreement and we could do better. On this part } \\
\text { I take the responsibility. We should have title } \\
\text { agreement with him. But you know it can be } \\
\text { resolved favorly. In term of delivery, it was } \\
\text { very clear who was negligent. I meant if you } \\
\text { are not satisfied, there are so many ways to } \\
\text { resolve. We should not resolve it being } \\
\text { aggressive...anyway..so that is kind of } \\
\text { experience.." (BE1-2) }\end{array}$ \\
\hline Past experience & $\begin{array}{l}\text { “..As entrepreneurs before, I had difficulties. } \\
\text { Difficulties in having single investor that } \\
\text { can..ermm where things can go rapidly } \\
\text { wrong.." (BE1-2) } \\
\text { "..It was early days in US as well, so when we } \\
\text { started. Then we decided that we would create } \\
\text { rather than take entrepreneurs whatever there is } \\
\text { social agenda, where there is very small } \\
\text { entrepreneurs, start with that basis first.." (BE1- } \\
\text { 2) }\end{array}$ \\
\hline $\begin{array}{l}\text { Second-hand } \\
\text { information }\end{array}$ & $\begin{array}{l}\text { Time range: April - September } 2019 \\
\text { The contents involve information on founders' } \\
20 \text { years' experience in strategic planning, } \\
\text { marketing and branding in agencies such as } \\
\text { Batey Ads, Saattchi\& Saatchi and Dentsu } \\
\text { Young \& Rubicam. (BE1-3) } \\
\text { The content involves information on } 13 \text { past job } \\
\text { listings where } 5 \text { of them are founder of business } \\
\text { start-ups and the rest are consultant, marketing } \\
\text { director, lecturer and account. (BE1-4) }\end{array}$ \\
\hline
\end{tabular}

This case is based on real Fintech based entrepreneur and company, but the entrepreneur and company are being renamed to preserve the anonymity requested. All details are otherwise accurate except where confidentiality or competitiveness issues arise, in which case the data have been suppressed or generalised

\section{CASE STUDY AND DISCUSSION\& RESULTS}

\section{A. Alertness: Scanning and Search}

Entrepreneurial alertness has become a key construct in entrepreneurship [18], [25], [26], mostly been explored within entrepreneurial studies that highly impact by innovation [27]. The informant, Fintech based entrepreneur established the first important component in alertness by scanning and searching information available in market Evidence (EAS1-1) has shown that informant has high level of "curiosity" to explore and search every aspect such marketing, technology, etc. This dimension of alertness aids lay the foundation of cognitive frameworks and reflect entrepreneur to be persistent in their attempt to investigate new ideas. Scanning and searching happened when entrepreneur starts to behold multiple possible since no systematic strategy is deployed [13]. Business opportunity only can be recognized through information gathering and the efficiency of information [28]. This dimension of alertness assists entrepreneur in developing a wide array of relevant information which can benefit them in attaining expert performance. The scanning and search aid lay the foundation for developing cognitive capability that reflects the belief (self-esteem) about the external world [18]. The evidence (CO3-1) and (CO3-2) portrayed how the entrepreneurs' self-esteem (belief) is been developed through alert dimension of scanning and search.

P1: Alert scanning and search developed self-esteem (belief) and enhance the entrepreneur's intention to pursue specific opportunity.

\section{B. Alertness: Association and Connection}

Association and connection is the second dimension in alertness that focuses on receiving information and making enlargement based on how information is applied. Multiple possibilities are considered, and unique connections are constructed. Evidences of (EAS2-1), (EAS2-2) and (EAS23) have shown that Informant associates and connects data on multiple sides of issue faced by investors and connect and incorporated them into inference. At this level, cognitive associations will depend on entrepreneur's expectation and experience [18]. Evidence (CO2-1) portrayed the creativity of informant which basically developed through alert evaluation and judgement. The judgement and evaluation on how Fintech can integrate intelligence into where people had to use their money effectively. Association and connection signify the entrepreneurs' capability to bond together formerly unconnected information. Consequently, association should be correlated to individual creativity, the ability of individual to generate novel and innovative business ideas [18], [29]. Evidence (EI2-1) and (EI2-2) demonstrated an intuition of informant to explain his action in entrepreneurial domain. Entrepreneurial Intuition is noted as ta construct for 


\section{THE FINTECH BASED ENTREPRENEURS' INTENTION: A SIGNIFICANT ENTREPRENEURIAL ALERTNESS TOWARDS ENTREPRENEURS' INTENTION IN FINANCIAL SERVICES TRANSFORMATION}

research within opportunity recognition is defined as the dynamic progression by which entrepreneurial alertness captures entrepreneurs' ability to select information. The entrepreneurs' intuition can be seen from evidence (EAS41) and (EAS4-2).

P2: Alert association and connection developed intuition (cognitive capacity) and enhance the entrepreneur's intention to pursue specific opportunity.

\section{Evaluation and Judgement}

The aspect of judgement is argued to be one of the important elements in alertness. Thus, the boundaries of third dimension of alertness, evaluation and judgement is extended to further assess and estimate either judgement is exercised if opportunity arises from new information [30]. Evidence (EAS2-1) described founders' alertness through associating his past difficulties in business and connects those with information he found in a market. In addition, evidence (EAS2-2) found the association of his difficulties on finding funds and connect it with scanned information from market to come up with possible finance-technology based business opportunities.

P3: Alert evaluation and judgement developed creativity (cognitive capacity) and enhance the entrepreneur's intention to pursue specific opportunity.

\section{Cognitive Ability}

This notion on the cognitive ability can be responding to the ability of entrepreneurs to discover new opportunity best refers to "innovativeness". The individual innovativeness has been addressed by [31] as the awareness towards opportunity as one of significant ability for entrepreneurs. EAS has mostly been explored within entrepreneurial studies that highly impact by innovation [26]. This portrayed the importance of EAS disposition in predicting EI within Fintech start-ups since Fintech behavior is highly impact by innovation. Evidence (CO1-1) portrayed the innovativeness of informant in exploring effective way using technologybased solution (Fintech) to cater issues in financial services market. At the same time, evidence (CO1-2) provides a dimension on disruption innovation pertaining how effective this idea (Fintech) would disrupting the traditional financial services but in a better way. Cognitive ability such creative and innovative are developed through the alert scanning and search dimension [15]. Thus, the evidence of alert scanning and search (EAS1-1) shown that informant has high level of "curiosity" to explore and search every aspect such marketing, technology and others become the foundation in developing "innovativeness" of founder.

Most recent researchers have continued to advance debates that alertness implicates a proactive stance in regard to a number of cognitive capacities and processes such as prior to knowledge and experience, recognition of pattern, skills in processing information from market and environment and social interactions [18], [21]-[23], [32]. Proactive is, by all means, refer as the ability of an individual to identify opportunities without been affected by any obstacles or constraints [33]. Proactiveness of founder (informant) is portrayed by evidence (CO5-1) Informant has ability to identify new opportunity even when there was a financial constraint he had to endure. The alertness implicates a proactive stance of informant in regard to his past success and failure business experience and skills in processing information from market. Entrepreneur with proactive ability will actively reacted to environmental forces and developed through the dimension of alertness; association and connection by noting that this association and connection of knowledge into viable ideas are said to be proactive [18], [34]. In other terms, in [18] noted proactiveness as positive affectivity which defined as feelings that reflect a level of enjoyable or pleasant engagement with environment. This cognitive capability has a strong effect on cognition, in which information is entered into memory, processed and retrieved [18], [35]. This proactiveness has found to provide impact to entrepreneurial process such opportunity recognition [25] and strengthen the influence of alertness with entrepreneurial intention.

P4: Alert scanning, search, associate, connect, evaluate and judgement developed proactiveness (cognitive capacity) and enhance the entrepreneur's intention to pursue specific opportunity.

\section{E. Entrepreneurial Intentions}

The relationship between EAS and EI has been empirically recognized by the former researcher [22] that EAS postulates judgment and opportunity identification of an individual, thus facilitating to form the intention to pursue the opportunity. Furthermore, a recent empirical study from the Chinese context, EA has a significant role in opportunity discovery within the entrepreneurial process [36]. Adding to that, in [13] have confirmed a significant relationship between EAS as a cognitive factor of EI. Adding to that empirical study by [13] has confirmed that individual with strong entrepreneurial alertness tended to have strong entrepreneurial intentions. Evidence (EI1-1), (EI1-2) and (EI1-3) portrayed the founders' intention to pursue entrepreneurship from dimension of his perseverance, persistent and courage. Fig. 3 depicted the empirical models.

P5: Entrepreneurial Intention is developed through ones' alertness.

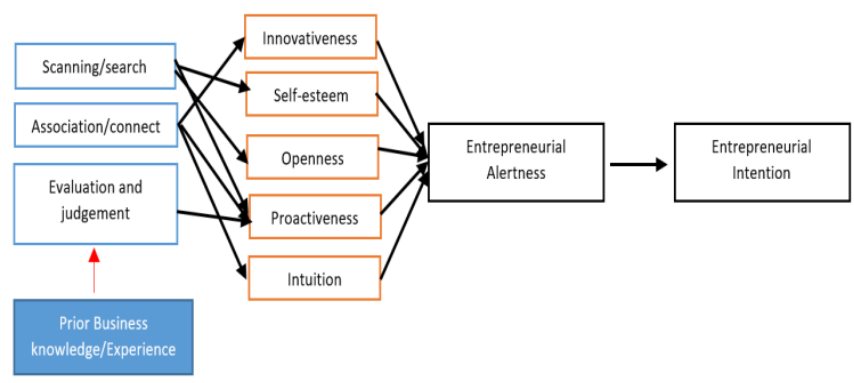

Fig. 3: Empirical models

\section{CONCLUSION}

This case study shows that Entrepreneurial Alertness featured by the sequential process of cognitive development comprises scanning, searching, association, connection, 
evaluation, and judgment, by significant is the process of information scan recognition, irrelevant information association and later business ideas evaluation as the sequential processes of cognitive development. Thus, development of alertness to respond the ability of entrepreneurs to discover new opportunity is mainly embodied in the deepened understanding of entrepreneurs of "How do Fintechbased entrepreneurs developed intention from alertness". With respect to Entrepreneurial Intention, Entrepreneurial Alertness (EAS) has an imperative role in opportunity discovery within the entrepreneurial process. As such, EA is closely associated with Entrepreneurial Intention (EI) which known as the self-acknowledged conviction of individual who intends to pursue a business opportunity and consciously plan to do so at some point in future [16].

\section{REFERENCES}

1. T. Philippon, “The Fintech opportunity,” NBER Working Paper Series, 201, 2017, pp. 1-24.

2. A. Mackenzie, "The Fintech revolution," London Business School, 26, 2015, pp. 50-53.

3. M. Fishbein and I. Ajzen, Belief, Attitude, Intention and Massachusetts: Addison-Wesley, 1980.

4. I. Ajzen, "Attitudes and persuasion," in The Oxford Handbook of Personality snd Social Psychology, K. Deaux and M. Snyder, Eds. England: Oxford University Press, 2012, pp. 367-393.

5. M. Conner, R. Povey, P. Sparks, R. James, and R. Shepherd, "Moderating role of attitudinal ambivalence within the theory of planned behaviour," British Journal of Social Psychology, 42(1), 2003, pp. 75-94.

6. N. Churchill and W. D. Bygrave, "The sntrepreneurship paradigm (I): A philosophical look at its research methodologies," Entrepreneurship Theory and Practice, 14(1), 1989, pp. 7-26.

7. M. Mustapha and M. Selvaraju, "Personal attributes, family influences, entrepreneurship education and entrepreneurship inclination among university students," Kajian Malaysia: Journal of Malaysian Studies, 33(Supp. 1), 2015, pp. 155-172.

8. T. Ramayah, N. H. Ahmad, and T. H. C. Fei, "Entrepreneur education: Does prior experience matter?," Journal of Entrepreneurship Education, 15, 2012 , pp. 6581.

9. B. A. Soomro and N. Shah, "Developing attitudes and intentions among potential entrepreneurs," Journal of Enterprise Information Management, 28(2), 2015, pp 304-322.

10. S. Z. Ahmad, S. R. Xavier, and A. R. A. Bakar, "Examining entrepreneurial intention through cognitive approach using Malaysia GEM data," Journal of Organizational Change Management, 27(3), 2014, pp. 449-464.

11. A. A. Mohsin, H. A. Halim, and N. H. Ahmad, "Competitive Intelligence among SMEs: Assessing the role of entrepreneurial attitude orientation on innovation performance," in Innovation, Finance, and the Economy, M. Bilgin, H. Danis, E. Demir and C. Lau, Eds. Cham: Springer, 2015, pp. 15-22.

12. T. Ramayah, N. H. Ahmad, and T. S. Hong, "An assessment of e-training effectiveness in multinational companies in Malaysia," Journal of Educational Technology and Society, 15(2), 2012, pp. 125-137.

13. I. M. Kirzner, "Creativity and/or alertness: A reconsideration of the Schumpeterian entrepreneur," The Review of Austrian Economics, 11(1), 1999, pp. 5-17. Behavior: An Introduction to Theory and Research.

14. V. H. Storr and A. John, "The determinants of entrepreneurial alertness and the characteristics of successful entrepreneurs," in Culture and Economic Action, L. E. Grube and I. H. Storr, Eds. Cheltenham: Edward Elgar, 2015, pp. 68-87.

15. B. Bird, "Implementing entrepreneurial ideas: The case for intention," Academy of Management Review, 13(3), 1988, pp. 442-453.

16. R. Hu, L. Wang, W. Zhang, and P. Bin, "Creativity, proactive personality, and entrepreneurial intention: The role of entrepreneurial alertness," Frontiers in Psychology, 9, 2018, pp. 1-10.

17. A. Biraglia and V. Kadile, "The role of entrepreneurial passion and creativity in developing entrepreneurial intentions: Insights from American homebrewers," Journal of Small Business Management, 55(1), 2017, pp 170-188.

18. J. Tang, K. M. M. Kacmar, and L. Busenitz, "Entrepreneurial alertness in the pursuit of new opportunities," Journal of Business Venturing, 27(1), 2012, pp. 77-94.

19. R. K. Yin, Case Study Research and Applications: Design and Methods. California: Sage Publications, 2017.

20. A. Ardichvili, R. Cardozo, and S. Ray, "A theory of entrepreneurial opportunity identification and development," Journal of Business Venturing, 18(1), 2003), pp. 105-123.

21. R. A. Baron, "Opportunity recognition as pattern recognition: How entrepreneurs "connect the dots" to identify new business opportunities," Academy of Management Perspectives, 20(1), 2006, pp. 104-119.

22. C. M. Gaglio and J. A. Katz, "The psychological basis of opportunity identification: Entrepreneurial alertness," Small Business Economics, 16(2), 2001, pp. 95-111.

23. N. J. Foss and P. G. Klein, "Entrepreneurial alertness and opportunity discovery: Origins, attributes, critique," in Historical Foundations of Entrepreneurship Research, H. Landström and F. Lohrke, Eds. Cheltenham: Edward Elgar Publishing 2010, pp. 98-120.

24. J. W. Creswell and C. N. Poth, Qualitative Inquiry and Research Design: Choosing Among Five Approaches. California: Sage Publications, 2017.

25. R. A. Baron and M. D. Ensley, "Opportunity recognition as the detection of meaningful patterns: Evidence from comparisons of novice and experienced entrepreneurs," Management Science, 52(9), 2006, pp. 1331-1344.

26. M. Z. Solesvik, P. Westhead, H. Matlay, and V. N. Parsyak, "Entrepreneurial assets and mindsets: Benefit from university entrepreneurship education investment," Education+Training, 55(8/9), 2013, pp. 748-762.

27. M. Z. Solesvik, "Entrepreneurial motivations and intentions: Investigating the role of education major," Education+Training, 55(3), 2013, pp. 253-271.

28. V. Puhakka, "Developing a creative-cognitive model of entrepreneurial alertness to business opportunities," Journal of Management and Strategy, 2(4), 2011, pp. 8594.

29. C. E. Shalley, "Effects of coaction, expected evaluation, and goal setting on creativity and productivity," Academy of Management Journal, 38(2), 1995, pp. 483503.

30. J. S. McMullen and D. A. Shepherd, "Entrepreneurial action and the role of uncertainty in the theory of the entrepreneur," Academy of Management Review, 31(1), 2006 , pp. 132-152. 


\section{THE FINTECH BASED ENTREPRENEURS' INTENTION: A SIGNIFICANT ENTREPRENEURIAL ALERTNESS TOWARDS ENTREPRENEURS' INTENTION IN FINANCIAL SERVICES TRANSFORMATION}

31. H. M. Campos, "The role of creativity in mediating the relationship between entrepreneurial passion and entrepreneurial alertness," RevistaBrasileira de Gestão de Negócios, 18(61), 2016, pp. 457-472.

32. A. Ardichvili, R. Cardozo, and S. Ray, "A theory of entrepreneurial opportunity identification and development," Journal of Business Venturing, 18(1), 2003, pp. 105-123.

33. M. A. Uy, K. Y. Chan, Y. L. Sam, M. R. Ho, and O. S. Chernyshenko, "Proactivity, adaptability and boundaryless career attitudes: The mediating role of entrepreneurial alertness," Journal of Vocational Behavior, 86 , 2015, pp. 115-123.

34. S. A. Alvarez and J. B. Barney, "Discovery and creation: Alternative theories of entrepreneurial action," Strategic Entrepreneurship Journal. 1(1-2), 2007, pp. 11-26.

35. A. M. Isen, "Missing in action in the AIM: Positive affect's facilitation of cognitive flexibility, innovation, and problem solving," Psychological Inquiry, 13(1), 2002, pp. 57-65.

36. R. Hu, L. Wang, W. Zhang, and P. Bin, "Creativity, proactive personality, and entrepreneurial intention: The role of entrepreneurial alertness," Frontiers in Psychology, 9, 2018, pp. 1-10.

\section{AUTHORS PROFILE}

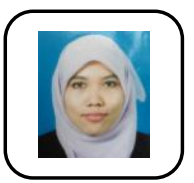

First Masrina Nadia MohdSalleh a quality-oriented lecturer in INTI International College Subang with nearly 7 years' experience in teaching, assessing, preparing modules and marking from various institutions such UNIKL, Taylors University, Nilai University and Linton College University. Currently pursuing Doctor of Philosophy in UTM Kuala Lumpur with the highest qualification of Msc in Finance, Investment and Risk from University of Kent, United Kingdom, BBA Hons in Finance and Diploma of Business Studies from UniversitiTeknologi Malaysia (UiTM).A keen planner and organized person.Equipped with industry's experience from DRB Hicom as Investor Relation Exec and MiTCOSdnBhd (Petronas) to accommodate a challenging, stimulating and rewarding career opportunity as full-time lecturer to be affiliated with a prestigious institution and able to enhance my skills, qualities, knowledge, attitude, value of time and strength in conjunction with institutions goal and objective.Registered member of Fintech Professionals Association (FPA). Current publications and research activities are as follows (1) "An Empirical Study on the Customers' Satisfaction on Fintech Mobile Payment Services in Malaysia". (2019). International Journal of Advanced Science and Technology. Vol. 28, No. 16, pp. 390-400. (2) "Consumer Acceptance and Adoption towards Payment-Type Fintech Services from Malaysian Perspective". (2019). International Journal of Advanced Science and Technology. Vol. 28, No. 15, pp. 148-163. (3) "The e-wallet usage as an acceptance indicator on Fintech in Malaysia". (2019). Journal of Social Sciences and Humanities Vol 4, No 20, pp.282-299. (4) "Systematic Literature Review on Fintech in Malaysian Financial Services". 1st Scientia Academic Conference 2019. (5) "Systematic Literature Review on Fintech in Malaysian Financial Services". (Revising). (6) "The Ideal of TH Framework to Promote Knowledge Talent: A Malaysian Case" (7) "The "Ideal" TH Model Framework to Promote Knowledge Talent: a Malaysian Case". (2018). Her research interest area include Fintech, Finance Behavior, Techpreneurship, Derivatives, Risk Management and Stock Markets Behaviour.

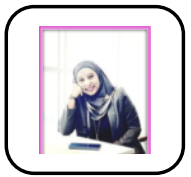

Dr.RahayuTasnim equipped with 20 years of both industry and academic experiences, having been in the Port of TanjungPelepas and Takaful Nasional, and in UniversitiTun Abdul Razak and Multimedia University, before becoming the VP Academic of Netherlands Maritime Institute of Technology. Currently is a senior lecture in MalaysiaJapan International Institute of Technology (MJIIT) UniversitiTeknologi Malaysia. She holds $\mathrm{PhD}$ (Entrepreneurship) from UniversitiTeknikal Melaka Malaysia, MBA (Technology Entrepreneurship) from International Business School, UniversitiTeknologi Malaysia, and B. Management (Hons) Finance from UniversitiSains Malaysia. She also comes with vast

consulting experiences and has established her own businesses in tourism and training. At the same time, she has helped more than 250 startups grow, with UpinIpin and MyTeksi (now Grab) as among her notable start up projects. Rahayu has also reached out to hundreds of industry players for potential ventures and projects. She brands herself as a linchpin, who connects the necessary dots, and making a difference, in her own unique ways. To date, she has published more than 20 research paper in different international journals including "I'm Loving It!" What Makes the Successful Entrepreneur Affectively Committed to Entrepreneurial Performance?" (2014). Journal of Applied Management and Entrepreneurship, 19(2), 27 and "Playing Entrepreneurship: Can Games Make a Difference? (2013). Entrepreneurial Practice Review, 2(4), 4-16. Her research interest focuses on entrepreneurship and neuromarketing.

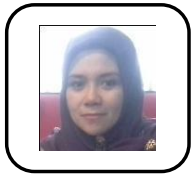

ShalizaAlwiis a lecturer in the School of Accounting and Finance in Taylor's University, Malaysia. She holds BBA from UUM, MBA from Charles Sturt University, Australia and pursuing $\mathrm{PhD}$ in Finance at Taylor's University, Malaysia. She has got eight years experienced at industry level and more than 15 years in teaching experienced. She has published number of finance papers in different international journals in the areas of Corporate Finance, Fintech, Derivatives and Islamic Finance.

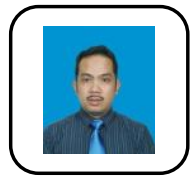

MohdShamsul Hassan equipped with 22 years in banking and finance industry experiences. Various of departments and tasks that he has been working with since 1997. Currently, he is working as an executive in Regional Office Johor Bahru. He holds BBA (Hons) from UniversitiKebangsaan Malaysia, Bangi. MBA (Strategic Management) from and presently pursuing DBA in AzmanHashim International Business School, UniversitiTeknologi Malaysia. His research interest focuses on Fintech, R\&D Management and Technology Management.

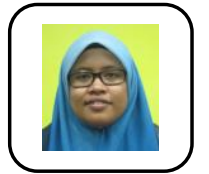

Noorfaizah Md Zainudinis an entrepreneur and currently established her owned business with the experienced in retails industry more than 15 years. Get her first degree in Civil Engineering (Hons.) from UniversitiTun Hussein Onn Malaysia, MBA from International Business School UniversitiTeknologi Malaysia and presently pursuing DBA in AzmanHashim International Business School UniversitiTeknologi Malaysia. Currently she's working on her research related to adventure tourism business. Her research interest focuses on entrepreneurship, marketing and technology management. 